\title{
GCU
}

Glasgow Caledonian

University

University for the Common Good

\section{Gender-sensitive approaches to extension programme design}

Jafry, Tahseen; Sulaiman V., Rasheed

Published in:

Journal of Agricultural Education and Extension

DOI:

10.1080/1389224X.2013.817345

Publication date:

2013

Document Version

Early version, also known as pre-print

Link to publication in ResearchOnline

Citation for published version (Harvard):

Jafry, T \& Sulaiman V., R 2013, 'Gender-sensitive approaches to extension programme design', Journal of Agricultural Education and Extension, vol. 19, no. 5, pp. 469-485.

https://doi.org/10.1080/1389224X.2013.817345

\section{General rights}

Copyright and moral rights for the publications made accessible in the public portal are retained by the authors and/or other copyright owners and it is a condition of accessing publications that users recognise and abide by the legal requirements associated with these rights.

Take down policy

If you believe that this document breaches copyright please view our takedown policy at https://edshare.gcu.ac.uk/id/eprint/5179 for details of how to contact us. 


\title{
Gender-Sensitive Approaches to Extension Programme Design
}

\author{
Tahseen Jafry* and Rasheed Sulaiman V
}

\section{Abstract}

Purpose

Though women are engaged in farming and play a major role in almost every agricultural operation, they continue to receive very limited extension support. While several interventions have been made to address this 'gender' bias in extension delivery, there continues to be a shortfall between the kind of support that is provided and the needs and demands of rural women. This gap between supply and demand needs to be addressed in order to improve the lives and livelihoods of women in the rural farming sector.

\section{Design/methodology/approach}

This paper presents the salient features of a new consultative process for designing gender-sensitive and demand-led programs for rural women. The process was pilot tested at three diverse locations in India.

\section{Findings}

This new approach is important for three reasons. Firstly, it addresses women's real needs through an analysis of household-level information about their livelihoods, aspirations and opportunities for sustainable income generation. Secondly, this approach builds on a database that allows collection, storage, retrieval and analysis baseline information; considers feasibility studies; identifies and develops potential suitable interventions; and reflects on the possible contribution of the potential interventions to meeting the needs and aspirations of women. Thirdly, this approach offers scope for ensuring convergence of interventions by different agencies, as everyone can use the same database to plan, select and monitor their interventions.

\section{Practical Implications and Originality/Value}

This approach if adapted and used in different contexts could help organizations design enhanced interventions to bridge the supply and demand gap of the support provided and the requirements of rural women, thereby achieving improved results.

Key Words

agricultural extension, gender, demand-led, programme design

Paper type

Research Paper

Number of words:

7254(all-inclusive from Abstract to References)

*Corresponding Author 


\section{Gender-Sensitive Approaches to Extension Programme Design}

\section{Introduction}

Despite the focus on women in agriculture over the past 25 years, they continue to be comprehensively neglected by extension services (Buchy \& Basaznew, 2005). This 'neglect' of women farmers' requirements by extension services is not only due to lack of awareness of gender issues, but also due to a limited understanding of the needs, desires and aspirations of women working in this sector. Women constitute $43 \%$ of the total global agricultural workforce: were they to have the same access as men to land, technology, financial services, education and markets it would be possible to increase agricultural production, and reduce the number of hungry people in the world by 100-150 million (FAO 2011). This pressing fact has brought into sharp focus the need to re-examine the nature of the influences upon current approaches towards achieving gender equity in the agricultural sector and to consider changes to those approaches which may be required.

Women farmers are the backbone of the agricultural workforce and are engaged across several activities ranging from production, harvesting and processing. They often lack capital, information, access to markets and technologies, knowledge and skills to transform or transcend subsistencelevel activities to earn enough to overcome poverty. Attention to women's concerns and priorities in development policy has been evolving since the early 1970's. However, while extension provision in developing countries remains at a low level for both sexes, in comparison to men women tend to avail themselves less of the existing provisions (Meinzen-Dick et al., 2010). This gender gap therefore hinders women's productivity, reducing their contributions both to the agricultural sector and the achievement of broader economic and social development goals (OECD, 2011). In short, the existing approach to help rural women in developing countries achieve food security and income from sustainable agriculture appears to be falling short of expectations. There is a lack of continuity between what is currently being supplied by agricultural extension, advisory programs, services, and what is needed by women who are engaged in the agricultural sector to help them achieve a better livelihood (Sulaiman et al., 2003).

This paper argues for developing demand-led gender-sensitive approaches for reaching out to rural women and presents an approach that has been developed along with trials run in India. The paper begins with an overview of the discussions around gender and agricultural extension in Section 2 and outlines the limitations of existing approaches. Section 3 offers an overview of the 'New Consultative Design Process' (NCDP) for delivery of agricultural extensions services to rural women. The methodology adopted to identify the new design process is illustrated in Section 4 . The findings from the study are presented in Section 5 and the discussion is in Section 6 . The conclusions to the approach are presented in Section 7.

\section{Gender and Agricultural Extension}

Starting in the early 1980s extension services began paying closer attention to gender issues. Before that women's role was seldom acknowledged or highlighted as being integral to the agricultural landscape. Though current extension programmes identify the need to include women, there is often a failure to recognise that women's needs vary considerably to men's, as both are often involved in different agricultural activities. Men and women farmers also have varying degrees of access to assets, information, markets, credit and other services, factors which facilitate agricultural development. Porter \& Sweetman (2005) consider that it is essential to critically examine the factors preventing or enabling implementation of development programmes in the interests of women, as this answers the question of why women remain politically and economically marginalised despite continued focus on gender equity on the global stage. Although agricultural extension and rural 
advisory services play a crucial role in the transfer of knowledge, information and skills through training and demonstrations (Davis et al., 2012), globally many of the programmes implemented today tend to engage more with male farmers and farmers from better-off socio-economic groups. This may be attributed to gender bias and inadequate poverty-focused targeting (Doss and Morris, 2001; Carter and Weigel, 2011).

To address the issues of relevance and focus, a range of interventions has been identified and 'tested' in some countries, where efforts are being made to move away from top-down technologydriven, male-dominated approaches towards more gender-sensitive methods (Quisumbing and Pandolfelli, 2010). For example, efforts have been made by governments and agencies to increase the number of female extension and advisory service agents to enhance women's access to extension services and increase participation and productivity in the agricultural sector. Whilst there is some evidence which suggests that more female extension agents would provide more and better-targeted information, and that women farmers prefer female extension officers (Due et al., 1997), there is little data to suggest that increased numbers of female extension agents have made substantive changes in women's agricultural productivity or improved their participation in agricultural activities (Berger et al., 1984).

There are also many examples of community-based approaches for reaching out to rural women as alternative mechanisms for extension and advisory support - for example, Farmer Field Schools (FFSs), co-operatives, farmer organisations, civil society organisations, women's self-help groups and more recently, advances in information and communication technologies (ICTs). Although Dethier and Effenberger (2012) posit that farmer organisations would benefit the poor by helping them reach economies of scale and obtain credit and other services which they would not have been able to achieve individually, there remains little by way of evidence on the long-term impact of these alternative approaches to extension. With regard to this, Najjar et al. (2012) call for more research to understand and explore how FFSs can enhance gender equality. Davis et al. (2012) consider that whilst much is documented as 'grey' literature, the long term impacts of FFSs as cited in peerreviewed journal articles remain unclear.

Women's self-help groups that are linked to social networks and are built upon social capital are other alternatives to the targeted diffusion of information, although access to information and support doesn't guarantee effective, meaningful and timely provision of services. Numerous studies have been conducted on the impact 'micro-finance' has on the economic productivity and social well-being of women (Reddy \& Manak, 2005; Gine and Karlan, 2009; Ashraf et al., 2010; Norren, 2011; Haile et al., 2012 ). These studies reveal that there are benefits to be accrued by rural women such as expansion in women-owned enterprises, increased number of women opening their own bank accounts and improved decision-making in married households. It must be highlighted, however, that the delivery of financial services ought to be tailored to women's different needs and interests (Kabeer, 2005) whereas credit and loan packages should be designed to meet the changing needs of women throughout their lives (Quisumbing and Pandolfelli , 2010).

Fischer and Qaim (2012) have called for a better understanding of the conditions under which collective action is useful and have asked through what mechanisms potential benefits emerge. At the same time, there is an over-dependence on participatory rural appraisals and focused group discussions as a way to identify women's needs and priorities. The centralised planning and topdown approaches currently followed by agricultural extension programmes have failed to put women farmers at the heart of the consultation process. It is also becoming increasingly clear that agricultural projects and programmes are not being formulated with an eye on the diversity of women's groups or specific interests (Sulaiman et al., 2005). Neither are they based on consultations with other agencies which attempt to support rural women. 
Participatory techniques such as participatory rural appraisal and rapid rural appraisal have been used extensively by scientists to better focus their research on the priorities and constraints of the poorest, and especially women. Johnson et al. (2003) note that the use/incorporation of participatory approaches still requires convincing evidence and a better understanding of the tradeoffs associated with using participatory methods. In other words, is the effectiveness of research dependent on giving intended beneficiaries a voice in the setting of research agendas? The question therefore arises whether serious investment should be made in developing institutional capacity in using participatory approaches.

The introduction of ICTs into extension and rural advisory services can be an important turning point in revamping the provision of support to women (Dethier and Effenberger, 2012). They can be used for providing information on weather, prices and profitable income diversification possibilities (Chapman and Slaymaker, 2002). Despite much support for the diffusion of ICTs in rural areas, gender disparity in the access to ICT services continues (World Bank, FAO and IFAD, 2008). While most of the ICT initiatives are disseminating new information and knowledge useful to rural women, many are not able to make use of it, due to lack of access to complementary sources of support and services (Sulaiman et al., 2011).

Gladwin et al. (2001) call for the development of programmes which focus not on agricultural/food production but on the development of interventions which increase women's income and improve their livelihoods. In today's climate, agricultural extension/rural advisory services must look beyond just the transfer of new technology and information to play a part in capacity development, strengthening innovation processes, building links between rural women and other agencies and fostering institutional and organisational development to support the bargaining position of women farmers (Sulaiman and Hall, 2004).

Given this, extension and advisory services are becoming more pluralistic (Birner et al 2009) and are increasingly considered as an integral component of agricultural innovation systems (Klerkx et al, 2010; Faure et al 2012; Sulaiman and Davis, 2012). The significance of which cannot be underestimated in the context of reaching rural women; since women form a significant proportion of the working poor in rural areas and reaching them requires collaboration with several types of actors as is dictated by agricultural innovation systems approach. Despite these pluralistic inroads to extension and advisory service provision, Sulaiman et al. (2005) recognise that there is a specific need for the development of gender-sensitive approaches to extension and advisory service provision which is built around a wider livelihood profile of women and is designed to address/tackle poverty via improving the lives and livelihoods of women. An approach that they consider will complement and add value to other existing approaches to extension and advisory service provision, including the innovation systems framework. They consider that what is required across the rural sector is a radically different approach to targeting rural women who work in agriculture and this involves finding new ways to help rural women express and articulate their demands, needs and aspirations as well as selecting potential interventions that will help them get out off poverty. In the context of India, a review by the Planning Commission on the implementation of development programmes for rural women called for "fresh thinking and an overhaul of the design, resource mobilisation and implementation machinery" for improving performance (Planning Commission, 2007). The current research was mainly undertaken to address this policy concern and led to the development of a new demand-led and gender-sensitive approach to designing programmes for women. 


\section{The New Consultative Design Process for Reaching Rural Women (NCDP)}

The NCDP methodology is a radical approach to the delivery of extension services which dispenses with the existing "top-down" method currently used by donors, governments, NGOs and the private sector and engages with women farmers' needs and aspirations from the outset.

The three-stage approach:

1) Engages with an analysis of household-level information about women's livelihoods and the opportunities that exist for sustainable income generation.

2) Works with the women to pinpoint the agricultural interventions needed and determines which are feasible for the area in question.

3) Identifies support networks within reach of the communities - rather than imposing interventions which may simply be impossible to facilitate.

The process assumes that improving the ability of women to demand more from extension will enable development initiatives to be more focused towards their local needs, desires and hopes. The NCDP approach or "toolkit" has the potential to be adopted and tested by a variety of organisations working in developing countries, and has an inherent flexibility that allows it to be adapted for communities and individuals facing very different sets of challenges.

This process begins with an initial diagnosis consisting of the gathering and analysis of baseline information such as types of agro-ecosystems present, land-use patterns, animal husbandry, and information on any allied agricultural enterprises. It is also important to understand food security issues at household level. A profile of women's livelihoods in the particular community is also built up by gathering information on specific agricultural activities, any constraints faced by the women in the course of these activities and the type of support that would help overcome those constraints. It is crucial that women's aspirations are central to the design process, and these are determined during the first stage. Information is then collected about the support and service networks available for the location where the intervention is planned, as well as details of organisations involved in the agriculture sector - such as local government departments, research and training organisations, NGOs, financial institutions and local traders.

The second stage, identification and selection of interventions, involves conducting a feasibility study based on the aspirations and activities identified in Stage 1. It requires more specific interactions with the client/customer and the agencies or organisations likely to be potential partners in any initiative. The success of the new programme and its chosen initiatives will depend on nurturing and building partnerships between such providers and the community. At this stage, the women's aspirations are identified only as "ideas for exploration". The strengths and weaknesses of any activity and the kind of support and services required to turn it into real livelihood opportunities are also considered. From this exercise, a shortlist of activities with the most potential to succeed is drawn up.

In the final stage of the design process, a final selection of project options and their identified support needs is made. A local stakeholder workshop is held with the community and any potential partners to initiate a thought process on the implementation of the project design - a crucial approach to achieve a convergence of ideas, actions and goals. Creating this dialogue also ensures that work at grassroots level is targeted and demand-led. Another key part of the programme is the marshalling of necessary human resources and the development of skills and expertise. This can be 
assisted with formulation of business plans and strategies, analysing risk, and creation of a monitoring and review system - all features of large-scale businesses which may be unfamiliar to rural women working at small-scale subsistence levels.

Social inclusion means ensuring that everyone feels they are able to contribute and be involved in their local community. As part of the design process, it is important to identify the power structures, institutions and political actors that maintain and encourage processes of discrimination and disadvantage. Conducting a social analysis or assessment of the programme being designed highlights issues ranging from landless rights to empowerment which should be taken into account in the final design. This leads to development that is not only more responsive but also more accessible to vulnerable and poorer women in the community. Conducting a gender analysis on the intervention with the highest chance of success is a further vital step in the design process, thereby ensuring that issues of equity and equality are unequivocally addressed.

\section{Methodology}

This section details the evolution of the NCDP into its current form. In 2005, the research team reviewed the implementation of programmes for women in agriculture in India and suggested a new approach to design gender-sensitive, demand-led programmes for women. The new approach was aimed at providing guidance on how to develop meaningful programmes for women via a process of identifying relevant interventions and consider the potential contribution of the proposed intervention to the lives and livelihoods of rural women. The main purpose of the current research was to field test this 'consultative design process' approach with rural women and communities so that it could be adapted on the basis of learning and feedback. To implement this, the team decided to first cross-check their rationale and thinking for a new approach by asking the following research questions:

How far the existing programmes currently implemented for rural women meet their needs for support and how are they designed?

How can we develop, field-test and fine tune a better demand-led and gender sensitive approach for reaching rural women?

\section{Rationale for a New Approach}

The nature of existing women-specific agricultural programmes in terms of their scale and relevance to the needs of rural women was studied by collecting information from 2 districts in India (Prakasam District in Andhra Pradesh and Pudukkottai District in Tamil Nadu). The research team interacted with organizations (Government, NGOs and private sector) who were implementing programmes for rural women in each of the districts and with women self-help groups/farmer interest groups who were active in the project area. Information related to funding and reach of the different interventions as well as to the operational challenges in implementing existing womenspecific programmes was collected and analysed. The findings from this study were then shared with the same stakeholders in these districts in formal workshops. The results from this research (discussed under 4.1) clearly revealed a mismatch between the kinds of support that women look for, or those that are relevant for them, and the nature of programmes being offered to them. The research also highlighted the need for a different approach to collecting and analysing information to respond to the demands of rural women and to designing relevant programmes for them. 
To test the consultative design process we collected information from women from selected villages in 3 states through participatory group interviews. Specific research questions associated with different stages of this research is provided in Box 1 . We randomly selected 30 villages in Minjur Block of Tamil Nadu, 45 villages in Gumma Block in Orissa and 24 villages in Mawphlang Block of Meghalaya for this field testing. The information collected included land use pattern, household food security, primary sources of income, women's livelihood profile and the aspirations that women identified for themselves. To explore the feasibility of various aspirations and activities identified by the women, we interacted with the same group of respondents in the same villages. Discussions were held with several agencies/organisations available in the region, namely traders, finance providers, development departments and research organizations, all of which could potentially support these activities.

Interactions and discussions with these different stakeholders helped in the analysis of the strengths and weaknesses of the various interventions. In addition, they helped in evaluating the kind of support that is required for any of the activities to become an important livelihood option. The feasibility study helped in shortlisting the viable options and in identifying the organizations that could support the selected interventions. The project team shared the methodology, database and findings of the pilot study with the stakeholders (at the block, district and state levels) by organizing a workshop in each of the three locations.

The NCDP methodology has been available online since 2009 through the website www.reachingruralwomen.org, where data collection forms and schedules used by the research team can be accessed and adapted for different countries and varying circumstances. The methodology and materials are accompanied by a "Guide for the Development of Programmes for Rural Women", which provides a clear description of the steps involved. The pilot testing conducted in the three Indian states suggested that initial investment in creating the database saves time and resources later in the programme, since the process is iterative and the same resource can also be used for evaluation and monitoring progress.

\section{Results}

\subsection{Nature of on-going interventions (Rationale for a new approach)}

Analysis of existing programmes aimed at rural women clearly revealed several limitations in their content, design and impact. These are discussed below.

Content: Most of the programmes for women in agriculture, implemented by government departments such as agriculture, animal husbandry, fisheries or sericulture, are subsidy- and inputfocused. Programmes implemented by other rural development organisations also have a higher allocation for distribution of inputs and provision of financial support. Other components included technical training, formation of groups, exposure visits, provision of revolving funds and microcapital assistance, and support for construction of working sheds. Despite some rural enterprises initiated in sericulture, dairying, goat rearing, chick rearing, vegetable production and rope making providing income, rural women face several constraints in managing these enterprises. Limited access to markets and lack of skills in understanding and responding to markets have restrained several potentially viable enterprises from expanding. Women, especially the poorest, do not have access to the right packages of support (technical, financial, logistical, marketing and business) to ensure that these activities remain successful. Most of these enterprises are managed by the women as individual activities.

Approach: The programmes/schemes are supply-driven and not demand-led. Programmes are designed centrally (at national or state levels) and implemented based on uniform guidelines with 
practically no flexibility to change norms and ways of working. No mechanism exists to understand women's real needs for support and there is a lack of consultation in identifying the interventions as well as the beneficiaries of these interventions. A majority of the rural women in both the districts are engaged in agricultural labour and livestock rearing. However, the majority of the programmes/schemes being implemented do not meet the requirements of this majority of women.

Funding, Reach and Poverty Relevance: There was a complete lack of awareness by women of the different programmes being implemented by different agencies. This clearly reveals that the programmes did not penetrate to the grass roots level. By way of design too, these programmes also target only a small fraction of the women population. Many of the programmes only reach the better-off farmers. Funds available for programmes targeting women are meagre, and with these meagre funds, the programmes reach only a fraction of the economically active women. Considering the funding, approach and effective reach, the programmes being implemented do not have any great relevance except for research or piloting purposes. If these programmes are to make any scalable impact on poverty, more resources (financial as well as human) will be necessary. Designing and delivering relevant programmes for women in agriculture therefore requires a great deal of exploration.

\subsection{Women's Livelihoods and Aspirations}

The majority of women are engaged as labourers in all the three locations (Table 1 ) and so programmes for rural women should be relevant to these categories to have better impact.

The second major activity women are involved in is livestock in both Minjur (milch animals and poultry) and Mawphlang (poultry and piggery). Livestock (poultry and goats) is the third most important activity for women in Gumma. The second most important activity for women in Gumma is collection of forest products and this includes mostly non-timber forest products. Women labourers and those involved in small livestock, therefore, should be the two major clients for any 'women in agriculture' programmes.

The study revealed that women want to improve their standard of living and live a quality life. Those who could articulate their aspirations talked about constructing better houses and providing better education to their children. Except for the few women who are constrained by caste, occupation and religious, all of them want to improve their income by engaging in some of the activities/occupations which they currently see as relevant (Table 2).

Though many women in all the locations are keen on starting some non-farm business activity, none of them were able to suggest the kind of support and services they might require for doing the same, except credit. All believed that if they could get credit, they could engage successfully in these activities. This clearly reveals their lack of experience in setting up new activities and also the lack of awareness and knowledge about other kinds of services and support (technical training, entrepreneurial skills, market links, etc.) which would be essential.

Interactions with the groups of women who prefer the same activity and also with the other agencies (traders, financiers, development departments and research organizations) that can potentially support these activities helped in analyzing the strengths and weaknesses of the proposed interventions. It also helped in evaluating the kind of support that is required for any of the activities to become an important livelihood option. The feasibility study revealed that only a few of the proposed interventions have the potential to be successful: these are indicated in Table 3. 
The results of this analysis were presented in a workshop to the different stakeholders in the three states and based on the feedback received from these consultations, the research team finalized the approach currently termed the "New Consultative Design Processfor Reaching Rural Women" (NCDP), as detailed in Section 3 above.

\section{Discussion}

The results from this research clearly reveal the mismatch between the nature of support that women look for, or that which is relevant to their needs, and the nature of programmes currently on offer. The research also highlights the importance of a different approach to collection and analysis of information in response to the demands of rural women and the designing of relevant interventions for them. Both these elements have implications for design of the relevant programme for rural women perse.

\section{Need for organizing wider support for rural women}

Rural women clearly need a "handholding" approach that also includes an integrated set of support and services (including technical support). They also need access to markets. Their capacity to respond to market changes also needs strengthening. Ultimately they need a range of support organisational, marketing, technical and enterprise development. However, this is often not available. Public sector organizations such as government departments of agriculture do not have the necessary skills to provide this integrated support. Therefore, they have to collaborate with others who can provide this expertise. The authors consider that this "hand-holding" or mentoring is required for a given period of time, or until the women feel they have developed sufficient capacity to manage their new/emerging enterprise(s).

\section{Importance of partnerships in programme design and implementation}

Integrated support to women can be ensured only if different agencies with varied and complementary skills interact and share their expertise. However, many government departments generally tend not to work together and there is weak interaction between them. Public sector-NGO interactions are weak too. Work force shortages are common and every staff member is under pressure to meet targets on a number of programmes involving distribution of subsidies and inputs. Programmes are designed centrally (at state or national level) and implemented with uniform guidelines. Districts and blocks tend not to have any flexibility to modify these. This is adversely affecting the performance and implementation of programmes on the ground. The new design process directly challenges the need for more integration and the need for more external support which must come from outside agencies such as financiers, business service providers, community resources and pro-poor social entrepreneurs.

\section{Need for an alternative demand-led and gender-sensitive approach in designing programmes}

Programmes for rural women need to be designed specifically based on the livelihood/activity profile of the clients/customer, their support requirements, and the leveraging of capital, human resource and market opportunities that could be harnessed to provide support. Pilot testing of the NCDP has demonstrated that this new approach has the potential to support organizations in designing demand-led programmes for rural women. It has the potential to support rural communities, especially in developing countries, which face varying socio-economic and environmental challenges. It is now hoped that this new approach to delivering agricultural 
extension services to rural women will serve as a template to be adopted and adapted by other countries in order to support the agricultural growth that vulnerable communities in developing nations urgently need. The authors consider that this new approach to delivering agricultural extension services to rural women serves as a template to be adopted and adapted by other countries in order to support the agricultural growth that vulnerable communities in developing nations urgently need.

\section{Conclusions}

Though several attempts have been made by extension agencies during the past few decades to improve on the accessibility to rural women, there is a mismatch between the types of support rural women receive and what they really want. If women are to be better served by extension, a new approach is required to designing and implementing programmes for them. Enabling rural women to bring to the fore their aspirations and desires for improving their livelihoods sits at the heart of the 'new consultative design process' (NCDP) discussed in this paper. It recognizes the fact that providing demand-led rather than supply-led programmes is the key to unlocking the potential of women who work in the agricultural sector. What rural women need is an integrated support and service network that includes credit, information, technical and business skills and market facilitation. Needless to say, this requires a convergence of interventions by various stakeholders. The NCDP approach provides opportunities for the selection of potential interventions and provision of varied support from different stakeholders.

The need to address gender issues in agriculture has most recently been given new global recognition and push at the Global Conference on Women in Agriculture (GCWA 2012) where it was stated that "by failing to invest in women farmers we are handicapping ourselves in the quest for sustainable and more productive agriculture systems and more food-secure societies".

\section{Acknowledgements}

The authors which to acknowledge funding support from the Department for International Development (DFID), London, UK and the United Nations International Forum for Agricultural Development (IFAD), Rome, Italy.

\section{References}

Ashraf, N., Karlan, D., Yin, W. (2010) Female empowerment: Impact of a commitment savings product in the Philippines, World Development, 38(3), pp 333-444

Berger, M., DeLancy, V., Millencamp, A. (1984) Bridging the gender gap in agricultural extension, Washington DC, International Center for Research on Women.

Birner, R., Davis, K.E., Pender, J., Nkonya, E., Anandajayasekeram, P., Ekboir, J., Mbabu, A., Spielman, D.J., Horna, D., Benin, S. \& Cohen, M. (2009) From Best Practice to Best Fit: A Framework for Designing and Analyzing Pluralistic Agricultural Advisory Services Worldwide. Journal of Agricultural Education and Extension, 15(4), pp. 341_355.

Buchy, M. and Basaznew, F. (2005) Gender-blind organisations deliver gender-biased services: the case of Awasa bureau of agriculture in southern Ethiopia. Gender Technology and Development, 9(2), pp. 235-251.

Carter, J. and Weigel, N.; 2011; Targeting Women in Rural Advisory Services (RAS), a+rd Network 
Brief No 1

Chapman, R. \& Slaymaker, T. (2002) ICTs and rural development: review of the literature, current interventions and opportunities for action. Working paper 192, London: Overseas Development Institute.

Davis, K., Nkonya, E., Kato, E., Mekonnen, D.A., Odendo, M., Miiro, R. \& Nkuba, J. (2012) Impact of Farmer Field schools on Agricultural Productivity and Poverty in East Africa. World Development, 40(2), pp 402-413.

Dethier, J.J. \& Effenberger, A. (2012) Agriculture and development: a brief review of the literature. Economic Systems, 36 (2), pp 175-205.

Doss, C.R. \& Morris M.L. (2001) How does gender affect the adoption of agricultural innovations? The case of improved maize technology in Ghana. Agricultural Economics, 25 (1), pp 27-39.

Due , J.M., Magayane,F. \& Temu, A.A. (1997) Gender again - views of female agricultural extension officers by small holder farmers in Tanzania, World Development, 25 (5), pp 713-725.

FAO (2011) The State of Food and Agriculture 2010-11, Women in Agriculture, Closing the Gender Gap for Development, , Rome, Food and Agriculture Organisation of the United Nations.

Faure, G., Yann Desjeux \& Pierre Gasselin (2012): New Challenges in

Agricultural Advisory Services from a Research Perspective: A Literature Review, Synthesis and Research Agenda, The Journal of Agricultural Education and Extension, 18:5, 461-492

Fischer, E. and Qaim, M. (2012) Linking smallholders to markets: determinants and impacts of farmer collective action in Kenya. World Development, 40 (6), pp 1255-1268.

GCWA (2012) Synthesis Report, Global Conference on Women in Agriculture, 13-15 March 2012. New Delhi, India.

Gine, X. and Karlan, D. (2009) Group versus Individual Liability: Long Term Evidence from Philippine Microcredit Lending Groups, Yale University Working Paper.

Gladwin, C.H., Thomson, A.M., Peterson, J.S. \& Anderson, A.S. (2001) Addressing Food Security in Africa via Multiple Livelihood Strategies of Women Farmers. Food Policy 26 (2), pp 177-207.

Haile, H. B., Bettina, B. \& Folmer, H. (2012) Microfinance and female empowerment: Do institutions matter? World Studies International Forum, 35 (2012), pp 256- 265

Johnson, N.L., Lilja, N. \& Ashby, J.A., (2003) Measuring the impact of user participation in agricultural and natural resource management research. Agricultural Systems, 78 (2), pp 287-306.

Kabeer, N. (2005) Is micro-finance 'magic bullet' for women's empowerment? Analysis of findings from South Asia. Economic and Political Weekly, 40 (44/45), pp 4709-4718.

Klerkx, L., Hall, A. and Leewuwis, C (2010) Adaptive Management in Agricultural Innovation Systems: The Interactions between Innovation Networks and Their Environment. Agricultural Systems 103 (6): 390-400.

Meinzen-Dick R., Quisumbing,A., Behrman, J., Biermayr-Jenzano, P., Wilde, V., Noordeloos, M., 
Ragassa,C., \& Beintema, N. (2010) Engendering agricultural research. Paper prepared for the Global Conference on Agriculture and Rural Development, 28-31 March. Montpellier, France.

Najjar, D., Spaling, H. \& Sinclair, A.J. (2012) Learning about sustainability and gender through Framer Field Schools in the Taita Hills, Kenya, International Journal of Education and Development, In press.

Noreen, S. (2011) Role of Microfinance in Empowerment of Female Population of Bahawalpur District. International Conference on Economics and Finance Research, IPEDR 4, Singapore, 2011, IACSIT Press.

OECD; 2011; Women's Economic Empowerment; Issues Paper, DAC Network on Gender Equality (GENDERNET)

Planning Commission (2007) Report of the sub-group on Gender and Agriculture, New Delhi: Planning Commission, Government of India.

Porter. F. \& Sweetman, C. (2005) Editorial 2. In F.Porter and C. Sweetman (Eds) Mainstreaming gender in development: A critical review, Oxford: Oxfam.

Quisumbing, A. R. \& Pandolfelli, L. (2010) Promising approaches to address the needs of poor female farmers: resources, constraints and interventions, World Development, 38 (4), pp 581-592.

Reddy, C.S. \& Manak, S. (2005) Self Help Groups: A keystone of Microfinance in India- Women empowerment \& social security, New Delhi, APMAS

Sulaiman V.R., Jafry, T. \& Ashok, M.S (2005) Programmes for Women in Agriculture: Emerging Lessons and Ways Forward. In Samanta, R.K. (ed) Empowering Rural Women-Issues, Opportunities and approaches, Delhi: The Women Press.

Sulaiman, V.R., Jafry T.\& Ashok M.S. (2003) Cafeteria for women in agriculture, NCAP Working Paper 4, New Delhi, National Centre for Agricultural Economics and Policy Research.

Sulaiman, V.R. \& Hall, A. (2004) Towards extension plus: Opportunities and Challenges, Policy Brief 17, New Delhi, National Centre for Agricultural Economics and Policy Research.

Sulaiman, V.R., Kalaivani, N. J., Mittal, N. \& Ramasundaram. P. (2011) ICTs and Empowerment of Indian Rural Women: What can we learn from on-going initiatives, CRISP Working Paper 2011-001, Hyderabad, Centre for Research on Innovation and Science Policy.

Sulaiman, V.R and Davis, K. (2012) The New Extensionist; Roles, Strategies and Capacities to Strengthen Extension and Advisory Services, GFRAS Position Paper, Lindau, Global Forum for Rural Advisory Services.

World Bank, FAO \& IFAD (2008) Gender in Agriculture Source Book, Food and Agriculture Association of United Nations and International Fund for Agricultural Development, The World Bank. 
Table 1: Livelihood profile of women in the $\mathbf{3}$ pilot locations

Women Livelihood Profile

Maximum numbers of women are engaged as labourers in all the three locations (Table 1 ) and so programmes for rural women should keep this category as their main client.

Table 1: Livelihood profile of women in the 3 pilot locations

\begin{tabular}{|l|l|l|l|l|l|l|}
\hline & \multicolumn{3}{|l|}{$\begin{array}{l}\text { Minjur, } \\
\text { Tamil Nadivities }\end{array}$} & \multicolumn{2}{l|}{$\begin{array}{l}\text { Gumma, } \\
\text { Orissa }\end{array}$} & \multicolumn{3}{l|}{$\begin{array}{l}\text { Mawphlang, } \\
\text { Meghalaya }\end{array}$} \\
\hline & Number & $\%^{* *}$ & Number & $\%^{* *}$ & Number & $\%{ }^{* *}$ \\
\hline Labourers & 1332 & $\mathbf{5 3 . 3 2}$ & 3269 & $\mathbf{2 5 . 0}$ & 2314 & $\mathbf{3 6 . 0}$ \\
\hline Agriculture (Owned/leased) & 287 & 11.48 & 2376 & 17.0 & 1195 & 19.0 \\
\hline Livestock activities & 534 & $\mathbf{2 1 . 3 7}$ & 2361 & 18.0 & 1572 & $\mathbf{2 3 . 0}$ \\
\hline Collection of forest products & 46 & 1.84 & 2751 & $\mathbf{2 1 . 0}$ & 1413 & 20.0 \\
\hline Post harvest activities & 125 & 5.00 & 2188 & 17.0 & 0 & - \\
\hline Other activities & 164 & 6.56 & 136 & 1.0 & 129 & 2.0 \\
\hline $\begin{array}{l}\text { Total women involved in } \\
\text { different occupations }\end{array}$ & 2498 & - & 13081 & & 6882 & \\
\hline
\end{tabular}

** Note:

1. Women engaging in multiple activities would get counted against each activity.

2. Percentage figures indicate the percentages to the total women engaged in different occupations and not the actual number of women or economically active women 
Table 2: Activities identified by women for improving their livelihoods

\begin{tabular}{|c|c|}
\hline Location & Activities Identified \\
\hline $\begin{array}{l}\text { Minjur, } \\
\text { Tamil Nadu }\end{array}$ & $\begin{array}{l}\text { Small business: grocery, home provisions, small restaurants ( tiffin } \\
\text { centres), cloth shops; } \\
\text { Fishing; } \\
\text { Agriculture in owned/leased land; } \\
\text { Eco-tourism; Dairy; Poultry/feed manufacturing unit }\end{array}$ \\
\hline $\begin{array}{l}\text { Gumma, } \\
\text { Orissa }\end{array}$ & $\begin{array}{l}\text { Small business: shops selling, grocery, home provisions, cloths, tailoring } \\
\text { and tea shop; } \\
\text { Collective marketing of cashew by SHGs; } \\
\text { Agriculture/horticulture enhancement; } \\
\text { Value addition such as turmeric processing, grading and packaging, } \\
\text { masala making and packaging, making mixtures, eatables from rice; } \\
\text { value addition to tamarind, mango/jackfruit, lemon pickling; } \\
\text { Poultry: scaling it up; } \\
\text { Goatery: scaling it up; } \\
\text { Minor skills enhancement: bicycle repairs, electronic goods repair, } \\
\text { mechanical repairs }\end{array}$ \\
\hline $\begin{array}{l}\text { Mawphlang, } \\
\text { Meghalaya }\end{array}$ & $\begin{array}{l}\text { Piggery: scaling it up in the backyard; } \\
\text { Poultry: enhanced management practices; } \\
\text { Agriculture/horticulture enhancement; } \\
\text { Value addition to fruits (pear, plum, peach), pickle making and potatoes; } \\
\text { Eco-tourism }\end{array}$ \\
\hline
\end{tabular}


Table 3: Selected interventions that offers promise

\begin{tabular}{|l|l|}
\hline Location & \multicolumn{1}{c|}{ Activities Identified } \\
\hline Minjur, \\
Tamil Nadu & Ecotourism, \\
& $\begin{array}{l}\text { Dairying, } \\
\text { Value-addition in fish } \\
\text { Poultry farming }\end{array}$ \\
\hline $\begin{array}{l}\text { Gumma, } \\
\text { Orissa }\end{array}$ & $\begin{array}{l}\text { Value addition of farm/forest produce } \\
\text { Scaling up back yard poultry and goatery, } \\
\text { Collective marketing of cashew }\end{array}$ \\
\hline Mawphlang, & Value addition of farm/forest produce, \\
Meghalaya & Back-yard poultry and piggery, \\
& Agriculture/horticulture enhancement \\
\hline
\end{tabular}




\section{Stage 1: Diagnosis (obtaining and analysing baseline information)}

An initial round of interviews in the village locations via focussed group discussions with women farmers was conducted to answer the following research questions:

Step 1: What is the local situation in terms of the natural resource base and agriculture e.g. irrigated land, dry land, rain-fed, forest, water bodies and what types of community/social groups they belong to?

Step 2: What is the household livelihood status? E.g. what is their food security status and what are their main sources of income?

Step 3: What are women's livelihoods profiles e.g. What are the roles of women (and men) in agriculture, livestock, forest based activities, fisheries, post harvest activities and others?

Step 4: What are women's aspirations (their hopes, desires and dreams for their future and that of their family)? What are women's plans and aspirations to improve their livelihood and what activities would they like to engage in kinds of activities they would like to undertake for improving their livelihoods? What are the possible constraints in realizing their goals?

Step 5: What support and service networks exist? What do they need to achieve their aspirations;finance/marketing/training/governance/infrastructure/information/license permission.

Step 6: Based on the information collected what are the implications for programme design? What are the possibilities? What are the constraints? How do possibilities meet with aspirations? What is doable? What is not possible? What are the priorities? What is in or not in demand?

\section{Stage 2: $\quad$ Identification and Selection of Interventions}

On completion of collection of baseline information and following the identification of potential starters, a second round of more specific interactions with the women customers identified and the various agencies critical for the success of the initiatives was carried out.

Step 7: Feasibility study of women's aspirations that could be further explored for designing relevant interventions. This is done by conducting a SWOT analysis of the activities to provide information on the strengths and weaknesses of the different activities/aspirations identified and the kind of support that is required to turn them into real livelihood opportunities. This will lead to a list of 'best bet' interventions.

Step 8: Consider the 'best bet' intervention identified in step 7, conduct an analysis of support and services needed such as back-up support (including microfinance services, credit availability and access, market demand and supply of goods and services, market network, knowledge-based institutions and other service providers and value addition possibilities). The success of new programme and projects rests on the strengths of the partnership that can be nurtured between organisations and the community. Therefore, it is critical to identify the types of roles and functions, organisations and agencies can offer to help turn an idea into a real opportunity.

\section{Stage 3: $\quad$ Programme Design and Convergence}

Completion of stages 1 and 2 will lead to the identification of 3-4 programme options for the location(s). Stakeholder workshops will highlight the key issues associated with designing the potential programmes identified using this process.

Step 9: Convergence is critical. Bringing organisations together in one forum will allow for the exchange of ideas and information. Creating this dialogue ensures that work on the ground in the villages with the communities is targeted and demand-led. Is there a network of positive stakeholders that can be built up around each enterprise? Stakeholders are both individuals, communities and government/non-governmental organisations that can gain from the success 
of an initiative.

Step 10: Institutional arrangements to for various partners work together throughout the project (from inception to implementation and evaluation). There is no blueprint for generating optimal institutional arrangements and working in partnership. However, any new programme or project does need to indicate in detail what types of institutional arrangements that the project would be hoping to initiate.

Step 11: Social Inclusion is ensuring that everyone feels that they are able to contribute and be involved in his or her local community. Conduct a social analysis or assessment of the programme or project being designed to highlight issues ranging from landless rights to empowerment that could be taken into account in the final design. Key questions include what power structures, institutions and political actors maintain and encourage processes of discrimination and disadvantage and how can they be addressed?

Step 12: Getting the Gender Balance right. The roles that women play and the contributions they make to society, the economy and to family livelihoods are different from men. In terms of programme design, it is important to recognise these different roles and the corresponding needs and perceptions. Conduct a gender analysis to determine how the proposed intervention impacts on both women and men. 